\title{
The Gospel and the Flag: The Missionary Strands in the British Colonial Enterprise in Nigeria, 1841-1960
}

\author{
Kanayo Louis Nwadialor, PhD \\ Department of Religion and Human Relations, Nnamdi Azikiwe University, Awka \\ nwadialorkanayo@yahoo.com \\ Nwachukwu J. Obiakor, PhD \\ Department of History and International Studies, Nnamdi Azikiwe University, Awka \\ nwachukwuobiakor@yahoo.com
}

\section{Doi:10.5901/ajis.2015.v4n3p249}

\begin{abstract}
British colonial enterprise in Nigeria has often been discussed in the light of British commercial companies that began to operate along the coasts of West Africa from the 1840s. These commercial firms often obtained charters to administer different territories on behalf of the British government. These territories were further organized into Colonies and Protectorates and there was a resultant increase in British colonial interest in the regions. These Protectorates were eventually amalgamated in 1914 to form a single administrative unit and consequently, there was an effective establishment of British colonial rule in what later became modern Nigeria. However, much as this historical analysis might be empirical, there is an aspect of the history that appears not to have engaged enough scholarly attention in the recent past. The missionary strands in the British colonial enterprise in Nigeria are factors that seem to be neglected, yet without it; the history of British penetration into Nigeria in particular and effective colonial rule in general may not be complete. The British missionaries were in Nigeria for the spiritual and moral regeneration of the people, yet they cooperated with the British government in establishing British colonial administration in the area. Their invitation to the British colonial office for a military conquest of the "heathens" in the regions which they considered a basic prerequisite for effective establishment of Christianity, and their continued efforts to pacify the conquered people, predisposed them as the spiritual arm of British imperialism in Nigeria. Since the missionaries believed that European rule, rather than the existing African administration, facilitated their missionary enterprise, it was obvious that the establishment of British political authority would be looked upon as a welcome change. This is the missing link in the British colonial enterprise in Nigeria that the various sub-themes of this study have addressed.
\end{abstract}

Keywords: Gospel, Flag, Missionary, Colonialism in Nigeria.

\section{Introduction}

The colonial question is an important factor in the history of Nigeria. Nwosu (1998) agrees that it is as important as the voyage of discovery, the slave trade, or the world wars in shaping the destiny of the nations and peoples of the third world. It has been argued that missionary success in the countries of Africa and Asia began to be recorded following the establishment of European colonial presence and its structures, or the presence of European trading companies in those countries. It has equally been claimed that treaties signed between the colonial government and the different African ethnic nationalities before the formal establishment of colonial presence gave the missionaries a foothold in several places in Africa. Anene (1966) captures article seven of the so-called "treaty of friendship" signed between the representative of the British government and the peoples of what, in London Gazette of June 5, 1885 became the 'Niger District" by which the area came under the "gracious protection" of her Britannic Majesty thus; "all white ministers of the Christian religion shall be permitted to exercise their calling within the territories of the aforementioned kings and chiefs who hereby guarantee them full protection" (p. 334). The aim of this paper, therefore, is to demonstrate how the marriage of convenience between the British colonial government and the European missionaries led to the eventual colonization of Nigeria. The paper will show how the enthusiastic support which the colonial administration began to give the missionaries predisposed the latter to even greater involvement in the work of colonial administration. No doubt the British government saw no better ally than the missionaries in entrenching colonial rule. The missionaries evidently had a tremendous amount of influence on the people, their influence deriving not from stringent laws and prosecutions and the 
fears that these could generate in the colonized people but essentially from the submissive influence of the teaching of Christian principles and this the colonial government considered an advantage in fostering colonial rule. Once the missionaries laid this foundation, the occupation and pacification of Nigeria were carried out with comparatively little difficulty and with relatively little expense in arms, money and men.

For the nature and purpose of this research, the data gathering was carried out from the perspective of the culture area approach. Kalu (1996) defines a culture area "as a geographical delineation of an area that has the same dominant and significant culture traits, complexes and pattern" (p. 9). This method has certain advantages. First, it aids an in-depth data collection. Second, it provides bases for comparison. Third, it aids interpretation by showing the place of the missionaries in British colonial enterprise in Nigeria. Since religion influences political, economic and social patterns, it is, therefore, possible to explore the impact of Christianity in British colonial interest in Nigeria both in the area of politics and socio-economic matters.

With regard to sources of information, both the primary and secondary sources of data collections were employed. The primary source was through oral interviews. In secondary source, related text books, magazines, journals, periodicals and Internet materials are the major sources.

\section{The Establishment of Christianity and the British Colonial Presence in Nigeria}

The effective establishment of Christianity in Nigeria began in the $19^{\text {th }}$ century after the failure attempts by the Portuguese Roman Catholic missionaries to plant enduring Christianity in the $14^{\text {th }}, 15^{\text {th }}$ and $16^{\text {th }}$ centuries. The $19^{\text {th }}$ century missionary enterprise was pioneered by the British Protestant missionaries that began to form in Europe in the wake of the reformation. The period was contemporaneous with the British government's commitment to put an end to the protracted slave trade which it had already proscribed to her citizens in 1807 but which continued as a major trade link between African chiefs along the coasts and some European countries. The British government therefore decided to enter into treaties with United States of America (USA) and other European countries to enable them enforce the parliamentary Act of May 1, 1807. Britain, therefore, authorized her Navy to capture foreign slave dealers on the high seas. The slaves thus captured were sent to Freetown in Sierra Leone. Thus Freetown became a conglomeration of people from several Nigerian and West African tribes. The Sierra Leone settlers were exposed to Christian doctrines and Freetown was to serve as a nerve centre for the spread of Christianity and civilization in West Africa.

The missionaries who eventually brought Christianity to Nigeria believed that if the $19^{\text {th }}$ century endeavour to plant Christianity in Nigeria was to be anything better than the earlier attempt, a more pragmatic approach has to be adopted. Thus, Thomas Fowell Boxton, a British humanitarian and philanthropist propounded the theory of "the Bible and the Plough" to evangelize and civilize Africa. The theory was based on the conviction that the most effective way to deal with the issue of the persistent slave trade in Africa and to plant effective Christianity and civilization was to involve three principal bodies in England: the British Government, the British traders and the British missionaries into a cooperative endeavour. To this, Okeke (2006) notes that:

Thomas Fowell Buxton believed that the most effective approach to the anti-slavery campaign was to involve the British government, humanitarians, interested businessmen and the British missionaries in a cooperative endeavour. The success of the venture they anticipated would mean a death-blow to the traffic in person. (pp. 4-5).

It was on this conviction that the 1841 Niger expedition was launched. Morehouse (1973) describes the Niger expedition of 1841, in which missionaries of the Church Missionary Society took an active part as a great imperial ambition for the extension of British influence in West African" (p. 81). The Niger expedition of 1841 actually marked the beginning of both the colonial government and missionary presence in Nigeria. Out of the three "civilizing" agencies that accompanied the expedition-British envoys concluding treaties with the various ethnic nationalities; missionaries preaching the gospel and individual merchants and trading companies conveying manufactured goods to the Niger and raw materials back to Britain-the missionaries appeared to have done the most in first of all getting a permanent foothold in Nigeria and in helping to get the local peoples to appreciate the need to establish a lasting relationship between themselves and the British government.

As in many parts of Africa, the British trading companies were first to establish relationship with the various peoples in what later became Nigeria before the British colonial government established itself in the territories. These trading companies were chartered to administer the territories on behalf of the British government before formal colonial administrative structures were put in place. But it was the missionary enterprise, which in several places followed behind the trading companies and the colonial presence, which saved the relationship between these agencies and the indigenous people from a total collapse. Nwosu (1978) confirms this view when he observes that: 
In several communities the relationship between the indigenous people on the one hand and the traders and colonial administrators on the other hand became so soured over the years that only an intervention of a kind provided by the missionaries would save the situation. (p. 41).

It is for this that the indigenous peoples originally saw through the missionaries, the better and a different kind of white man, those who came for the good of the people and thus soon began to transfer their perception of the white missionaries to the colonial administrators and traders especially as they were of the same colour and the people often saw close interactions (Ekechi, 1972). Thus it was the people's acceptance of the white missionaries that induced their acceptance of the British colonial officials, in spite of several bombardment, blockade and war. It is not surprising then that, having observed the role of many of his colleagues in the spread of British influence among the lbibio, a primitive Methodist missionary, in his private papers, discerned truth in and recorded the following humorous statement ascribed to a school boy in England and preserved by Ayandele (1966) thus:

Africa is a British colony. For this England is much indebted to her missionaries, when the missionaries arrived in a hitherto unknown part, he called the natives to him. When they have gathered around him he made them kneel down and closed their eyes. This done, he hoists the British flag and proclaim the colony British territory. (p. 30).

\section{The Missionaries as the Spiritual arm of British Imperialism in Nigeria}

African historians have continued to insist that the British missionaries in Nigeria, and indeed Africa, played significant roles in the colonization of Africa. They were regarded as colonial instruments for pacifying the conquered people and in many places supported the power organization of the colonial government. From the start, missionary propaganda in Nigeria was not just a religious invasion. In effect it was associated with a political invasion as well. Oostheizen (1968) opines that "the Church itself in African lived on imperial and political favour, and Christian missionaries were at times the spiritual wing of the colonial administrators. Indeed, the missionaries served as the spiritual arm of British colonial administration. There is no better evidence to this claim than that of the testimony of H.H. Johnson, himself one of the builders of British Nigerian who in 1911 told the British public that, in fact, the C.M.S. for good or for evil, has done more to create British Nigeria than the British government (Ayandele, 1966).

Although it can be said that it was the administrators that paved the way and the missions trailed gratefully behind, the former could not, in final analysis record any meaningful success without the missions. And the administrators realized this, as Afigbo (1980) puts it; the administration soon began to realize that the campaign against "superstition" and "barbarism" could not succeed if based alone on stringent laws and prosecutions for their breach; this campaign needed some ideological base and this, the missions supplied" (p. 195).

The maintenance of law and order especially during difficult times is indispensable for any administration to succeed. It has been shown that missionary activities were meant to prevent violent revolutionary actions during disturbed periods in Nigeria. Thus the missionaries constituted themselves into peace markers between the indigenous people and colonial officials often in fact appearing as defendants of the people. And by so doing, they won the people for the colonial administration showing, as it were, the better side of the white man. Colemen (1986) puts it this way:

The word "Christ" has always been identified here with the British Empire and the general feelings are that the missionaries have been the front tropes of the government to soften the hearts of the people and while people look at the cross white men gather the riches of the land. (p. 108).

There was indeed a time, especially during the period of the scramble for Africa, when the mission fields in Nigeria became swamped with missionaries to whom the imperial flag meant more than the cross of Christ, who had more regard for their white skin, European dignity, and superior status than they had for the brothers and sisters for whom Christ died, whose relationship even with the native ministers and other Church workers was one not of colleagueship but strictly official, always or too often, that of master and servant; at best their attitude to the congregation was one of paternalism. At this time, they were more interested in furnishing the British government, through the local official, with geographical and strategical data about Nigeria, which found their way to the war office and were used for military intelligence. Therefore, working hand in hand in many cases, with the British imperial agents the missionaries' purpose in Nigeria from the $19^{\text {th }}$ century onward was believed to be other than spiritual.

The keen interests which the missionaries had in local politics were not also hidden. Examples abound of cases where the missionaries did collaborate with the imperial agents, often they acted as their spies and agents and some of their converts were allies of European traders and government officials. Hence, Falola and Adediran (1983) conclude that "before the scramble for and the partition of West Africa by European powers, the missionaries had succeeded in preparing the ground for colonial rule" (p. 114). In a few cases, they have succeeded in drawing the local rulers into the 
orbit of various European powers. By the 1890s many of the coastal chiefs were under heavy obligations to the British government because of the aids they received through the missionaries. This type of indebtedness made the occupation of territories on the coast of West Africa relatively easy for the European powers.

H.H. Johnson, a British colonial official in Nigeria, once proclaimed that the missionaries of the C.M.S in Nigeria were doing more than the British colonial administration in the overall enterprise of establishing and fostering British colonial rule and in creating a consciousness of British presence in the country. Hence, it began to be asked by British colonial officials in Nigeria why European missionaries in Nigeria should not in fact become part of colonial administration. The missions were henceforth to become an arm of colonial administration as members of the British Empire.

\section{The Missionaries and the British Pacification of Nigeria}

From the start, missionary propaganda in Nigeria was associated with colonial aggression. In the background was the secular arm of British government, to be invoked when practicable. Up to the end of the $19^{\text {th }}$ century in Nigeria the Bible and the sword worked together, administrators appealing to missionaries to Christianize subjugated peoples. The belief among the administrative officers was that Christians were more loyal to the British administration than non Christians, apart from the fact that missionaries produced clerks for government and commercial concerns.

The Christian missionaries in Nigeria undoubtedly supported the colonial administration in their unprovoked attacks on the indigenous peoples in various parts of Nigeria, thereby contributing, just as the colonial government did, to the establishment of British rule. The C.M.S. laid their foundations in Nigeria between 1841 and 1857 and they were the most concerned in the period to get the protection of the British navy for their work. Their great success came at the end of 1851 when they got the British government to order the bombardment and occupation of Lagos. This was followed by the opening in 1853-60 of several stations in the interior of the Yoruba country, and on the Niger in 1857; their success was on the wave of the new imperialism developing in Europe.

The British bombardment of Lagos in 1851, according to Ayandele (1969), "was held by a missionary as a providential blessing that would open a way for the evangelization of other parts of Yorubaland' (p. 31). With regard to south Eastern Nigeria, Kalu (1978) argues that following the opening of the Igbo interior in South-Eastern Nigeria in what has been dubbed "Aro-Expedition" of 1901-1902, missionaries followed at the heels of invading soldiers behind the smoke of guns to establish their religion. Ekechi (1972) adds that before the British military expedition against the Aro Igbo of south-eastern Nigeria in 1902, father Le Roy had, in a memorandum to Paris, described the whole military operation being planned against the people as a civilizing expedition. And in his report in 1902, Father Leon Lejeune urged his missionary over lords in Paris to bring their full force to support the expedition, insisting that the war was necessary, and that both the C.M.S. and the Presbyterians gave their full support. A favourable disposition of missionaries to military expedition against Nigerian peoples was well expressed by a southern American Baptist missionary who, on the eve of a military expedition said, as preserved by Ayandele (1969), that "war is often a means of opening a door for the gospel to enter a country; a sword of steel often goes before a sword of spirit" (p. 33).

The missionaries also made the European government officials realized the need to pacify the peoples of the interior. With increased hostility by some local peoples, the missionaries saw no means of achieving success other than with some military backing. They believed that once European superior military strength was demonstrated, the Nigerian peoples would easily yield to their persuasion. Moreover, in a few places like Badagry, Lagos and Abeokuta, the missionaries' use of secular arms to bring momentary peace had shown them the need for such intervention. They therefore began to appeal to their home government to occupy territories in Nigeria so as to guarantee serene atmosphere in which Christianity and commerce would thrive.

The early missionaries also demanded protection from the British government as an inalienable right. Hope Waddell, the United Presbyterian mission pioneer in Old Calabar, refused to leave Britain in December 1845 until the government had given guarantee of every protection to the missionary party. The physical capacity of the secular arm, said the Foreign Mission Board in Edinburgh, must be impressed on the Efik and become a means of facilitating success among them (Ayandele, 1966). Even in northern Nigeria, by 1897 the C.M.S. with many of its missionaries had begun to look forward to a military subjugation of the region, which event they hoped would, as in southern Nigeria, open the door to the Christianization of northern Nigeria. The expectation of the C.M.S. was in keeping with the ideology that 'sword of steel' and the 'sword of spirit' should always go together in areas where people attempt to prevent intrusion of either the missionary or the administrator into the area. It is not surprising then that the society interpreted the military expedition against llorin and Bida as the beginning of the fulfillment of their hopes. The C.M.S.'s desire for military subjugation of the Fulani as a precursor for the Christianization of northern Nigeria should not therefore surprise us. In their progress 
towards Kano, they paraded themselves as knight errands of British imperialism, believing that by winning the north for the British the Christianization of the territory would be hastened. As Herbert Tugwell, an Anglican bishop of Western Equatorial Africa and leader of the missionary expedition said, England is the only hope of this country and the gospel the only power that can effectively set them free (Ayandele, 1966).

However, it is essential to understand the motive for missionary involvement in colonial aggression in Nigeria. Their objective at all times remained the Christianization of the Nigerian 'pagans'. But it was their considered judgment that the ultimate objective could not be actualized until certain conditions prevailed in Nigeria. Among these were peace and stability, the abolition of the slave trade, the evolution of money economy, and the creation in Nigeria of a society, industrial and 'civilized' similar to that of contemporary Europe. They were truly committed to the doctrine of the three C'sChristianity, Commerce and Civilization. When therefore Thomas Birch Freemen urged George Maclean of the Gold coast to protect the Christians in Badagry, and that the British should aid the Egba against all their enemies, when Gollmer of the C.M.S asked that the ljebu be attacked in 1856; when the same missionary saw the bombardment of Lagos as God's interposition for the good of Africa, when Charles Phillips, the educated African pioneer of Christianity in Ondo, called upon a national calamity to befall the Ondo so that they might become Christians, when the C.M.S. missionaries interpreted the military expedition against llorin and Bida as the beginning of the fulfillment of their hopes, When Hope Waddel demanded the British pacification of the Efik, when in 1902, Father Leon Lejenue urged his missionary over lords in Paris to bring their full force to support the Aro expedition, just to mention a few, they all believed that they were working for the spiritual salvation of the inhabitants and for their material well being as well. Though Ayandele (1966) defended the missionaries on their stance by saying that they were not necessarily a trigger happy set of people, that considering the nature of their mission and their perspective of the indigenous setting, those expeditions which they either inspired or supported or even sponsored were considered capable of producing positive results in the interest of the Christianization enterprise, yet the trouble was that the missionaries cooperated too closely with a government that was demonstrating its willingness to use gun-boat diplomacy to get the native people to do its will.

\section{The Missionaries and Economic Imperialism in Nigeria}

The years between 1860 and 1890 were ones of commercial struggles between the European companies, on one hand, and the African coastal tribes and Sierra Leonean merchants, on the other. The decade after 1850 marked the turning point in Nigerian history. Repeated attempts by the Europeans to penetrate the hinterland since 1832 by way of the River Niger-signaled by the famous Niger expeditions-had failed disastrously after twenty-two years of continuous effort to accomplish their object (Dike, 1966). True, in these years the Niger was charted, the people on its banks studied, and its commercial possibilities assessed; yet African opposition to penetration and the impediment posed by nature remained impregnable. But in 1854, owing to the death of Consul Beecroft, whom the Foreign Office had ordered to take charge of operations, surgeon commander William Baike found himself at the head of the expedition of that year. In this voyage, and for the first time, he proved that the use of quinine, as prophylactic or preventive would enable the Europeans to withstand the influence of the African climate and that quinine not only cures (African fever), but that it actually prevents it, and that by taking this invaluable drug while in unhealthy localities persons might escape totally unscathed. Dike (1966) notes that this discovery is worthy to be ranked with Cook's conquest of scurvy. Baikie led his expedition as far as Hausaland and returned to the coast without the lost of a single life. The event proved a turning point in Nigerian history. From 1854 therefore, the British traders, the missionaries and the government looked to the Nigerian hinterland rather than to the coast for trade, evangelism and empire. Their naked aim was to control the trade and missionary work in Nigeria. The successful efforts of the European trading houses to penetrate the interior destroyed the African Christians' livelihood. Those who had been trading in the Niger witnessed the intimate connection between the economic imperialism of the European merchant's houses, the change of policy of the C.M.S. Niger mission and the ensuing penetration of imperial forces. Everywhere Africans found themselves the victims of a new hardening attitude, an uninformed intolerance, a pushing and grasping for absolute authority. Okeke (2006) shares that "the missionaries and the traders could not avoid one another; their association created immense opportunities and opened up possibilities. But it was, equally, potentially problematic and difficult" (p. 25). African ministers of the Niger mission were closely related to, and sympathetic to the African merchants, and opposed the European trading houses. To eliminate this type of opposition from African ministers and to avoid any competition either from the African traders or other European nations, the various British firms operating on the Niger were united into one by Sir George Goldie into what was known as the Royal Niger Company; and Goldie obtained a charter for the company to govern the Oil Rivers Protectorate on behalf of the British government for the period of ten years. Goldie was able to use his political powers to exclude all commercial rivals 
especially the Africans. The Royal Niger Company's regime incorporated the evils of colonialism, such as its destructive violence and subordination of the economic interests of the governed in those of the ruling power, without its attendant benefits such as education or any other form of development. On occasions, its officials were guilty of great cruelty, not only to the local people but to their own employees. The company used its illegal monopoly to exclude African merchants from the Niger trade-this enabled it to lower both the prices given for produce, and the quality of the goods it supplied. Goldie, whose overt racism was untypical even of the age in which he lived, admitted the charges, but was undisturbed. African Christian merchants based in Lagos and Sierra Leone suddenly found that they had been made to look like foreigners on the Niger. Worse still so did the Delta peoples. The men of Brass, living on the margins of the salt water delta, depended on Niger trade for their livelihood. On February 4, 1885, the King and chiefs of Brass wrote a letter to McDonald of the Oil Rivers Protectorate, outlining their futile years of negotiation with the Royal Niger Company, their suffering, and their sequel. Isichei (1983) gives an account of the letter in the following words:

The ill treatments of the Niger Company are very bad. They said that Brass men should eat dust. According to their sayings, we see truly that we eat the dust. Our boys fired, killed, and plundered, and even the innocent provision sellers were captured and killed likewise...instead of we Brass people die through hunger we had rather go to them and die in their swords. (p. 364).

Christians of Brass and Bonny, along with their 'pagan' neigbours were the middle men who were being squeezed out of the trade. All the main cities of the Niger Delta coast were in a state of upheaval. In this struggle, it was obvious that the English missionaries sided with their English compatriots in business. Europeans were on the imperial move; politically penetrating into the interiors, religiously securing absolute control over the Christian congregations and the arrogance which accompanied imperial expansion was reflected in growing missionary intolerance of African customs and leadership. Nigerians saw all the elements of their local situation in great drama of being played out on the Niger. It appeared as multiple prongs of one large European intrigue to subdue them. Greed and complex were pushing European merchants to dislodge their African competitors and forcing stringent economic measures upon the local Churches. The native Christians who were originally the middle men of African trade between the Europeans on the coast and the interior Kingdoms were castigated by Goldie before Salisbury Square. According to Isichei (1983), Goldie wrote a letter to Salisbury Square on August 8, 1885, describing the educated Christian middlemen of the Delta trade as "disreputable coloured men under a mask of ardent piety. The local people were 'natives' whose light and intermittent labours the most earnest negrophile can scarcely wish to further reduce to the detriment of toiling artisans of Great Britain" (p. 364). In 1887, Robinson, a C.M.S. missionary on the Niger corroborated Goldie's letter in this form of colonialism; "how fully they believed that the White Traders are untrustworthy and that their country would be richer if the white men were banished" (Isichei, 1983: 365). Salisbury Square, certainly, was ready to accept the views of the European traders on the Niger. Besides, a new era had emerged when whites identified with whites. Although merchants and missionaries pursued different objectives, there seemed no reason why the relationship between the two elements should be estranged. After all, said one of the European missionaries in 1890, "the merchants are our European fellow countrymen...of the same flesh and blood as ourselves" (Ekechi, 1972: 59).

During these years, antagonism grew between European and African clergy. Exaggerated reports reached London of the low morals of the ministry and laity of the Niger mission; in the reports, charges included allegation of African 'backsliding' from Christianity, and of slave trading or at the least, holding of domestic slaves. Such early condemnations served inadvertently to increase pressure in England for introducing British authority.

\section{The Missionaries and Religio-Cultural Imperialism in Nigeria}

The cultural heritage of the Nigerian peoples had in the past been severely dealt with that it became doubtful whether much of the good values in Nigerian cultural heritage could be rehabilitated. Of all the agents of imperialism it was the missionaries who did the most devastating damage in the religious and cultural setting in Nigeria. The missionaries did not want the wealth from the Nigerian soil, nor the fruits of her forests, nor any portion of her soil, except when it was so demanded by the colonial authorities. The missionaries desired instead the conquest of the Nigerian soul. Theirs was an enterprise which was to result in the creation of a completely new social order which would wipe away most of the customs and institutions of the old society. They saw the indigenous world-views of the Nigerian peoples and their cultural milieu as unnecessary superstitions and unwarranted practices that called for subjugation and total extinction.

One striking feature of the missionary activities in Nigeria, and indeed the entire Africa, was the way in which the missionaries condemned the indigenous cultural and religious beliefs and practices. To this, Nwosu (1998) rightly points out that: 
In their sermons, in their open and private conversations with the indigenous people, in their prayer and committee meetings, and in every other gathering of the faithful, many missionaries condemned as evil every aspect of African religious and cultural life, including even people's names. (p. 56).

The converts were not allowed to participate in socio-cultural activities including initiation into traditional religiocultural societies. To become a Christian, the African convert had to become a European in every way, including abandoning his wives- a reminiscence of the behaviour of the Jewish Christians toward the gentile converts. Isichei (1976) adds that "both the evangelicals of the Niger mission and the Catholic Fathers were hostile to Igbo religion, not once, but repeatedly, in their writings and correspondence does one find Igboland described as the kingdom of Satan" ( $p$. 161). They did not see the indigenous religion of the people as one manifestation of that light which enlightens every man born into the world. Allied with, and in many cases inseparable from the British secular arm, missionary enterprise resulted, culturally, in the suppression of Nigerian social order. The missionaries' opinion was that there was something inherently evil in the nature of the people of Nigeria that made it impossible for them to perceive their true interestacceptance of the Christian faith and the political rule of Britain. Up to 1900 a favourable disposition to missionary enterprise became the undisguised policy of a set of administrators who, reflecting the religious side of Victorian England, believed that destruction of 'fetishism' was an essential part of their imperial task. In outlook, intention and action, they believed that Pax Britanica was in a sense also Pax Christi; for the moral and spiritual regeneration of the Nigeria 'pagans' lay in Christianity and civilization (Ayandele, 1966). The issue is that in the work of elevating Africans, foreign missionaries worked on the assumption that the African is in every one of his normal susceptibilities an inferior race, and that it was needful in everything to give him a foreign model to copy; no account was made of his peculiarities, his language enriched with traditions of centuries; his parables, many of them the quintessence of family and native histories, his model of thought, influenced more or less by local circumstances, which though crude, had their own tales to tell.

The missionaries had condemned many Nigerian customs and traditional institutions as 'heathenism' and, since the indigenous religions which they sought to displace permeated very many facets of African life, they ended up condemning virtually all African customs and traditions. This was especially because the missionaries themselves could not distinguish between Christianity and European civilization which they considered inseparable and jointly recommended to their converts. In this regard, converts were made to adopt European names which were considered the outward sign of the inward conversion from 'paganism' to Christianity. Consequently they became deluded with the idea that the less Africans they were the more Christians they become.

\section{The Inadequacy of the Missionary Education in Nigeria}

It has been said that the education which the missionaries gave to the Africans galvanized them into nationalist activities. This point has been made by Onunwa (1991), Ajayi (1965), Abernethy (1969), Nwadialor and Udezo (2011). These authors considered what may be described as the positive aspects of the educational enterprise. But they did not consider the inadequacy of the missionary education which was another very important negative dimension of missionary activity which portrays the missionaries in the light of British imperialism Nigeria.

Almost as by rule, all primary schools and virtually all teachers training colleges were owned and run by the missions. It was not until 1882 that the government first considered setting up its own schools and making contributions to existing ones. Until then, all schools were started on the initiative and with the support of the missions, and had remained in their hands. However, to the missionaries, education was viewed as an instrument for evangelization rather than as a tool for socio-economic and political empowerment. Hence, one of the most burning issues during the era of nationalism in Nigeria was the qualitative and quantitative inadequacy of western education. The missionary education was not geared to produce high level manpower but was directed to provide their converts with basic education so that they would be able to read and write and understand the basic Christian teachings. Osoba and Fajana (1999) join in saying that "the missionary programme of educating the 'natives' was consequently restricted initially to the limited objective of producing marginally literate Nigerians, preferably literate only in their own mother tongues" (p. 57). It was envisaged that the products of this education would operate in their social milieus and would, therefore, be able to transmit the new message of salvation to their own people. There was no question, for most of the $19^{\text {th }}$ century, of really introducing educational institutions geared to meeting the social and material needs of Nigerians. The main, if not exclusive concern of the mission schools was to produce school masters who were to graduate to catechists, deacons and then priests, while girls' schools were established mainly for the wives and fiancés of their male workers. There was, therefore, an antiintellectualism built into the missionary educational system. Again, with the full establishment of colonial rule in Nigeria, there was a major shift in the purpose, emphasis, content and medium of western education from religious-moral 
instructions in local languages to education for loyalty to colonial countries in that colonial countries' language, and for producing clerks. Rodney (1974) captures the situation in the following words:

The main purpose of the colonial school system was to train Africans to help man the local administration at the lowest ranks and to staff the private capitalist firms owned by Europeans. In effect, that meant selecting a few Africans to participate in the domination and exploitation of the continent as a whole. It was not an educational system that grew out of the African environment or one that was designed to promote the most rational use of material and social resources. It was not an educational system designed to give young people confidence and pride as members of African societies, but one which sought to instill a sense of defense towards all that was European and capitalist....the development of under development. (p. 240).

British expatriates were incredibly reluctant to initiate either political or educational policies considered likely to render the indigenous people more emancipated and independent. This was so because it was thought that such programmes would involve lowering the prestige of the European officials. Their educational programme was aimed at preventing the black man from challenging the colonial and white status quo. According to Ekechi (1972), "the recommendation of an inferior education system was a deliberate attempt on the part of the Europeans to keep the African in his place so that he would not seek complete social, economic and political equality with the western world" ( $p$. 187). In terms of teachers, the West Indians were often employed instead of the Europeans not only because of the lower cost involved, but primarily because they thought it was beneath a European to stoop to the level of the African. As to content, the schools equipped Nigerians with little more than an elementary knowledge of the English language for an economic future in which a senior clerkship was the upper limit of his permissible advancement. In terms of need and desire, there were hundreds of candidates for every school vacancy. This educational policy of the foreign missions can be likened to Plato's philosophy of education and Statecraft. For instance just as Plato calls for a class-based education for a class-structured society where individuals must aspire to remain in their prescribed class, the educational policy of the foreign missions was similarly structured and intended. Thus, it can be argued that the foreign missions were against any form of education not geared towards the realization of their missionary and colonial agenda.

The natives were not comfortable with the type of education which the missionaries provided. To this, Oduyoye (1978) maintains that:

The education policy of the missionaries with its concentration on minimal literacy and, after that, the development of manual and technical skills for the inculcation of agriculture and mechanical arts, prove unattractive to the emigrants from Sierra-Leone, who wanted their children prepared for University studies as then understood in England. (p. 284).

Consequently, one of the first issues to which attention turned in the mission-produced press of the 1880s was education. Leaders of thought began first to agitate for a change in educational policy, but unfortunately the Europeans paid little heed. Consequently, to achieve their ends these local Church leaders turned their attention to an intellectual fight for political emancipation which would enable the country to rectify the mistakes made in education by the European missionaries and the British government in Nigeria.

\section{Conclusion}

This study has shown how the missionaries, especially the British Protestants, had collaborated in the entire process that culminated in the establishment of colonial rule in Nigeria. The missionaries, from the beginning, did conceive the idea that it was necessary to change the existing social and political system in Nigeria. They sought the creation of a completely new social order which would wipe away most of the customs and institutions of the old society. They knew that for such an ambitious project to succeed they needed the massive support of the British government. Consequently, the missionaries began to impress upon the British government that colonization was a divine duty. In an attempt to gain public sympathy in Britain and make the government do their wish, the missionaries began to conjure tales of horror, slavery, warfare, carnage and terrible suffering going on in the West African hinterlands. The missionaries appealed to their government to save human dignity by pacifying the native tribes and opening the gate to civilize the region. These reports and appeals not only found audience among the European populace but began to influence official circles in Europe. Hand in hand with the task of changing the social system, the missionaries had the intention of removing some traditional rulers whom they regarded as stumbling blocks in their missionary activities. They thought that the chiefs were despotic and that it was because of this that they were able to prevent their subjects from receiving the gospel. On the other hand, they usually supported the chiefs in towns that accepted Christianity against those who did not and they also helped their supporters in the wars against their enemies. They further drew the attention of the British government to the vast resources of the interior and also made it abundantly clear that the commercial benefits of Europe would increase 
once peace and stability were restored. To the missionaries, the only way to bring this about was effective occupation by the British government. Thus ideologically, and to a certain extent in practice, a potentially violent intrusion was made into the social and political world of the Nigerian peoples with the advent of Christian missionaries.

It must be emphasized, however, that this collaboration was not born out of a conscious attempt to ensure the establishment of British imperialism as such, rather it was seen as a means to the end, for it was believed that in the chaotic situation of the $19^{\text {th }}$ century, only a serene atmosphere could ensure a fruitful germination of Christian ideas, and that only the British government could bring about this atmosphere. This is why Jowitt (2010) submits that "missionaries in fact undoubtedly in general welcomed the coming of colonial rule, because it brought about the more peaceful conditions in which the missionaries could operate, and not least, afforded protection to the missionaries themselves" ( $p$. 231). This was how in most parts of Nigeria, particularly in the South, Christianity paved the way for colonialism. It spread under the protection of the colonial powers; it benefited from the expansion of British Empire. In return it rendered special service to British imperialism by legitimizing it and accustoming their new converts to accept compensatory expectations of an eternal reward for territorial misfortune, including colonial exploitation. What all this means is that European missionaries in Nigeria in fact worked hand-in glove with the colonial administration and thus shared in every aspect in which the colonial administration was established in Nigeria.

\section{References}

Abernethy, D. (1969). The political dilemma of popular education. London: Oxford University.

Ajayi, J.F.A. (1965). Christian missions in Nigeria, 1841-1991: The making of new elite. London: Longman.

Anene, J.C. (1966). Southern Nigeria in transition, 1885-1960: The theory and practice in colonial protectorate. Cambridge: The University.

Ayandele, E.A. (1966). The missionary impact on modern Nigeria, 1842-1914: A political and social analysis. London: Longman.

Coleman, J.S. (1986). Nigerian background to nationalism. Benin City: Brobury and Wistron.

Dike, K.O. (1966). Trade and politics in the Niger Delta, 1830-1885: An introduction to the economic and political history of Nigeria. Oxford: Clarendon.

Ekechi, F.K. (1972). Missionary enterprise and rivalry in Igboland, 1857-1914. London: Frank Cass.

Falola, T.\& Adediran, B. (1983). Islam and Christianity in West Africa. Ile-Ife: University of Ife.

Jowitt, D. (2010). Christianity: A concise history. Ibadan: Kraft.

Kalu, O.U. (1996). The embattled gods: The Christianization of Igboland, 1841-1991. Lagos: Minaj.

Kalu, O.U.(1978). Protestant Christianity in Igboland. In O.U. Kalu (Ed.). Christianity in West Africa: The Nigerian story (pp. 308-322). Ibadan: Daystar.

Morehouse, G. (1973). The missionaries. London: Eyre Methuen.

Nwadialor, K.L.\& Udezo, B.O.S. (2011). The place of the Church in the rise of sustainable nationalism in Nigeria. In A.B.C. Cheigboka, T.C. Utoh- Ezeajugh \&.M.S. Ogene (Eds.). The humanities and sustainable development (pp. 381-387). Nimo: Rex Charles and Patrick.

Nwosu, L.U (1988). The religious factor in the history of West Africa. Owerri: Vivian and Vivian.

Oduyoye, .M.C. (1978). The planting of Christianity in Yorubaland, 1842-1888. In O.U. Kalu (Ed.). Christianity in West Africa: The Nigerian story (pp. 239-394). Ibadan: Daystar.

Okeke, D.C. (2006). People of the book: The Anglican mission in Igboland (vol 1). Enugu: Rabboni.

Onunwa, U. (1991). Missionary factor in African nationalism. Indian Mssiological Review, 30-38.

Oosthuzien, G.C. (1968). Post-Christianity in Africa. London. C. Hurst.

Osoba, S.O. \& Fajana, A. (1999). Educational and social development during twentieth century. In O. Ikime (Ed.).Ground work of Nigerian history (pp. 570-600). Ibadan: Heinemann.

Rodney, W. (1974). How Europe underdeveloped Africa. Abuja: Panal. 
